DOI: https://doi.org/10.24127/ajpm.v9i4.2685

\title{
ANALISIS KESALAHAN SISWA DALAM MENYELESAIKAN SOAL MATEMATIKA PISA PADA KONTEN CHANGE AND RELATIONSHIP
}

\author{
Dede Pranitasari ${ }^{1 *}$, Novisita Ratu ${ }^{2}$ \\ ${ }^{1 * 2}$ Program Studi Pendidikan Matematika FKIP Universitas Kristen Satya Wacana \\ ${ }^{*}$ Corresponding author \\ E-mail: $\quad \frac{\text { 202016010@student.uksw.edu }{ }^{1 *}}{\text { novisita.ratu@staff.uksw.edu }^{2)}}$
}

Received 14 Februari 2020; Received in revised form 30 September 2020; Accepted 30 December 2020

\begin{abstract}
Abstrak
Keberhasilan siswa yang kurang optimal terhadap literasi matematika dalam PISA tentunya dikarenakan siswa mengalami kesulitan sehingga menyebabkan kesalahan. Oleh karena itu, penelitian ini bertujuan untuk mengetahui jenis kesalahan yang dilakukan siswa SMA dalam menyelesaikan soal matematika PISA pada konten change and relationship. Penelitian ini merupakan penelitian deskriptif kualitatif. Subjek penelitian terdiri dari 3 siswa kelas X MIPA 3 SMA Negeri 1 Tuntang dengan jenis kesalahan terbanyak. Pengumpulan data dilakukan menggunakan tes dan wawancara. Hasil penelitian menunjukkan bahwa secara umum kesalahan yang dilakukan oleh ketiga subjek dalam menyelesaikan soal matematika PISA pada konten change and relationship berdasarkan NEA (Newman's Error Analysis) pada soal nomor 1, 2, dan 3 adalah kesalahan dalam memahami soal (comprehension), kesalahan dalam mengubah permasalahan pada soal ke bentuk matematika (transformation), dan kesalahan dalam menuliskan atau menyimpulkan hasil akhir (encoding). Kesalahan tersebut terjadi dikarenakan untuk menyelesaikan soal membutuhkan penalaran yang tinggi sehingga subjek mengalami kesulitan, kebingungan, dan kurang berminat baik dalam menyaring informasi atau menyelesaikan soal sesuai dengn prosedur matematika yang relevan.
\end{abstract}

Kata kunci: change and relationship; kesalahan; PISA.

\begin{abstract}
The success of the non-optimal students toward mathematics literacy in PISA is absolutely caused by the difficulties they had in which provoked failures and mistakes. Hence, this study investigated the types of mistakes that were done by senior high school students in doing PISA's mathematics questions, especially in 'change and relationship' content. It is a descriptive qualitative study. The participants of the study were students from X Math and Science 3 of SMA Negeri 1 Tuntang with the most plenteous types of mistakes. The data were collected from tests and interview sessions. The results of this study showed that the mistakes which were done by three subjects in doing PISA's mathematics questions written in 'change and relationship' content based on NEA (Newman's Error Analysis) number 1, 2, 3 were generally the failure in comprehending questions (comprehension), the failure in changing problems mentioned in the questions into mathematic format (transformation), and the failure in writing or concluding the final results (encoding). These errors occur because solving problems requires high reasoning so that the subject experience difficulty, confusion, and is not interested in both filtering information or solving problems in accordance with relevan mathematical prosedures.
\end{abstract}

Keywords: change and relationship; mistakes, PISA

This is an open access article under the Creative Commons Attribution 4.0 International License

\section{PENDAHULUAN}

PISA

(Programme for

International Student Assesment) merupakan sebuah program internasional yang diselenggarakan oleh
OECD (Organization for Economic Cooperation and Development) dimana program ini bertujuan untuk mengukur kualitas pembelajaran dari suatu negara yang berkaitan dengan pencapaian 
belajar siswa yang tepatnya berusia 15 tahun (Wilkens, 2011). Soal PISA sendiri dikembangkan berdasarkan 4 konten yaitu Shape and Space, Change and Relationship, Quantity, dan Uncertainty dimana masing-masing konten memiliki pokok pelajaran yang berbeda-beda. Sejak tahun 2000 Indonesia menjadi salah satu dari berbagai negara yang ikut berpartisipasi dan terlibat dalam program PISA. Keterlibatan yang dimaksud guna mengetahui sejauh mana perkembangan dan kemajuan pendidikan di Indonesia dibandingkan dengan negara-negara lain, namun hasil yang diperoleh masih belum memuaskan terutama pada literasi matematika dimana sejak tahun 2000 sampai 2015, Indonesia berada pada peringkat sepuluh terbawah (Elsa \& Syam, 2017). Hasil PISA terbaru tahun 2018 juga menunjukkan bahwa skor literasi matematika Indonesia masih jauh dari rerata internasional yaitu 379 dari 489 (OECD, 2019), sehingga hal ini dimungkinkan karena siswa mengalami kesulitan menyelesaikan soal PISA. Anggapan tersebut didukung oleh penelitian Murtiyasa \& Perwita (2020) yang mengatakan bahwa hasil studi PISA yang masih dibawah rerata disebabkan siswa belum terlatih dalam menyelesaikan soal bertipe PISA. Salah satunya adalah konten Change and Relationship (Perubahan dan Hubungan). Konten ini berkaitan dengan pokok pelajaran aljabar yang merupakan salah satu materi yang telah dipelajari pada tingkat SMP hingga SMA. Pada PISA 2003, konten change and relationship merupakan soal tersulit bagi siswa Indonesia (Stacey, 2011).

Hasil PISA tahun 2003 pada konten change and relationship, Indonesia mendapatkan skor 334 dimana skor tersebut masih sangat rendah dibandingkan dengan konten lainnya.
Sedangkan pada hasil PISA tahun 2012, literasi matematika Indonesia pada konten change and relationship hanya memperoleh skor 364 dan menempati posisi 3 negara terendah, bahkan jauh tertinggal dari negara tetangga seperti Singapura dan Vietnam yang memperoleh skor berturut-turut 580 dan 509 (OECD, 2012). Dengan demikian, kondisi ini mengindikasikan bahwa kemampuan siswa Indonesia dalam pokok pelajaran aljabar masih rendah, sehingga dimungkinkan siswa mengalami kesulitan. Fitrah (2017) mengungkapkan bahwa siswa terbiasa membahasakan matematika itu susah, rumit, dan sulit. Pendapat tersebut juga diperkuat oleh Stacey (2011) yang menyimpulkan bahwa salah satu soal tersulit adalah konten change and relationship. Oleh karena itu, hasil siswa dalam menyelesaikan soal-soal PISA yang masih rendah itu tentunya dikarenakan siswa mengalami kesulitan sehingga menyebabkan kesalahan.

Penelitian ini sejalan dengan yang disampaikan Novferma (2016) bahwa keberhasilan siswa yang kurang optimal terhadap pencapaian hasil belajar dimungkinkan karena terdapat kesulitan dalam diri siswa sehingga terjadi kesalahan. Murtiyasa, Rejeki, \& Ishartono (2020) mengatakan bahwa kesalahan siswa dijumpai pada tahap memahami dan mentransformasikan. Penelitian yang dilakukan oleh Wati \& Murtiyasa (2016) juga menyimpulkan bahwa kesalahan dalam pemahaman dan transformasi merupakan kesalahan yang lebih banyak dilakukan siswa dalam menyelesaikan soal PISA. Kesalahan yang dialami siswa cenderung pada kemampuan penalaran dan kreativitas siswa yang kurang dan rendah dalam memecahkan masalah konteks nyata dan memanipulasi ke dalam bentuk aljabar. Soal yang tergolong sulit, sebagian besar 
melakukan kesalahan memahami (Trapsilo, 2016). Faktor penyebab lainnya adalah siswa kurang terampil dalam menerapkan perhitungan ke dalam bentuk rumus, kurang melatih diri menyelesaikan soal yang berbasis konteks nyata (Cahyanto, 2017), serta siswa tidak teliti dalam membaca soal (Sholihah dkk., 2019) Penelitian yang dilakukan oleh Djadir, dkk. (2018) juga menyimpulkan bahwa siswa masih lemah dalam memodelkan kalimat verbal kedalam kalimat matematika, menentukan solusi untuk menyelesaikan masalah, dan ketrampilan dalam mengoperasikan juga masih lemah. Selain itu, sebesar $68,18 \%$ siswa kesulitan dalam memahami masalah, siswa tidak mampu menyelesaikan masalah, siswa juga tidak dapat memeriksa kembali hasil yang telah diperoleh (Mursalin, Fauzi, \& Israwati 2017)

Berdasarkan beberapa penelitian sebelumnya sudah banyak penelitian terkait analisis kesalahan siswa dalam menyelesaikan soal matematika PISA namun belum banyak ditemukan penelitian terkait analisis kesalahan siswa dalam menyelesaikan soal matematika PISA terutama untuk siswa SMA pada konten change and relationship. Salah satu teori tentang analisis kesalahan yaitu Newman's Error Analysis (NEA). Newman (White, 2010), saat seseorang mengerjakan soal matematika maka orang tersebut sudah melalui 5 tahap, yaitu: (1) reading (membaca soal); (2) comprehension (memahami soal); (3) transformation (transformasi); (4) process skills (proses penyelesaian); dan (5) encoding (penulisan kesimpulan).

Kesalahan-kesalahan yang dapat terjadi dalam menyelesaikan soal matematika dalam hal ini soal PISA konten change and relationship yang berkaitan dengan pokok pelajaran aljabar yaitu kesalahan dalam memahami masalah soal, tidak dapat mentransformasikan masalah ke dalam bentuk matematika, keteledoran dalam process skills, atau dalam menarik kesimpulan. Beda penelitian ini dengan penelitian sebelumnya yaitu pada penelitian ini akan menganalisis kesalahan siswa SMA dalam menyelesaikan soal matematia PISA konten change and relationship dimana penelitian sebelumnya dilakukan pada siswa SMP.

Berdasarkan penjelasan di atas, menunjukkan bahwa siswa masih melakukan kesalahan dan masalah dalam penelitian ini adalah bagaimana kesalahan siswa SMA dalam menyelesaikan soal matematika PISA pada konten change and relationship dengan menggunakan teori kesalahan Newman. Oleh karena itu, analisis kesalahan secara mendalam diperlukan guna mengetahui jenis kesalahan yang dilakukan siswa dalam menyelesaikan soal PISA sehingga prestasi matematika siswa Indonesia dalam PISA dapat ditingkatkan dan menjadi lebih baik. Berdasarkan uraian di atas maka penelitian ini bertujuan untuk mengetahui jenis kesalahan yang dilakukan siswa SMA dalam menyelesaikan soal matematika PISA pada konten change and relationship. pada siswa kelas X SMA berdasarkan NEA.

\section{METODE PENELITIAN}

Metode yang digunakan dalam penelitian ini adalah deskriptif kualitatif. Analisis kesalahan siswa dalam menyelesaikan soal matematika PISA berdasarkan tes dan wawancara. Pemilihan subjek diawali dengan pemberian tes PISA konten change and relationship kepada siswa kelas X MIPA 
DOI: https://doi.org/10.24127/ajpm.v9i4.2685

3 (27 orang). Tes yang digunakan dalam penelitian berupa soal matematika PISA konten change and relationship dan bentuk tes yang akan diberikan kepada siswa berupa soal uraian.

Tabel 1. Jenis kesalahan dan indikator kesalahan subjek.

\begin{tabular}{|c|c|}
\hline Jenis Kesalahan & Indikator \\
\hline $\begin{array}{l}\text { Reading } \\
\text { (membaca) }\end{array}$ & $\begin{array}{l}\text { a. Subjek tidak mampu membaca simbol, kata-kata, atau hal } \\
\text { yang memuat informasi utama pada soal }\end{array}$ \\
\hline (Jenis A) & $\begin{array}{l}\text { b. Subjek tidak mampu memaknai arti setiap kata, simbol, dan } \\
\text { istilah dalam soal }\end{array}$ \\
\hline \multirow{5}{*}{$\begin{array}{l}\text { Comprehension } \\
\text { (memahami) } \\
\text { (Jenis B) }\end{array}$} & $\begin{array}{l}\text { a. Subjek tidak mampu menyatakan informasi yang diketahui } \\
\text { dalam soal dengan benar dan lengkap }\end{array}$ \\
\hline & $\begin{array}{l}\text { b. Subjek tidak mampu memaknai informasi yang terdapat } \\
\text { pada soal }\end{array}$ \\
\hline & $\begin{array}{l}\text { c. Subjek tidak memahami apa yang ditanyakan dalam soal } \\
\text { dengan lengkap }\end{array}$ \\
\hline & $\begin{array}{l}\text { d. Subjek tidak mampu menyaring informasi yang relevan dan } \\
\text { tidak relevan (salah dalam menuliskan apa yang diketahui) }\end{array}$ \\
\hline & $\begin{array}{l}\text { e. Subjek tidak mampu mengumpulkan informasi yang } \\
\text { diperlukan (yang diketahui dan tidak diketahui dalam soal) }\end{array}$ \\
\hline \multirow{5}{*}{$\begin{array}{l}\text { Transformation } \\
\text { (transformasi) } \\
\text { (Jenis C) }\end{array}$} & $\begin{array}{l}\text { a. Subjek tidak mampu mengubah soal atau informasi pada } \\
\text { soal ke dalam bentuk matematika dengan benar }\end{array}$ \\
\hline & $\begin{array}{l}\text { b. Subjek tidak mampu merencanakan solusi dengan benar } \\
\text { untuk menyelesaikan soal }\end{array}$ \\
\hline & $\begin{array}{l}\text { c. Subjek tidak mampu menganalisa mana yang diperlukan } \\
\text { dan yang tidak diperlukan untuk dihitung }\end{array}$ \\
\hline & $\begin{array}{l}\text { d. Subjek tidak mampu menggunakan prosedur matematika } \\
\text { yang relevan }\end{array}$ \\
\hline & $\begin{array}{l}\text { e. Subjek tidak mampu menjawab soal dengan perspektif ilmu } \\
\text { matematika }\end{array}$ \\
\hline \multirow{3}{*}{$\begin{array}{l}\text { Process Skill } \\
\text { (penyelesaian) } \\
\text { (Jenis D) }\end{array}$} & $\begin{array}{l}\text { a. Subjek tidak mampu menyelesaikan soal dengan benar } \\
\text { sesuai dengan prosedur atau langkah-langkah yang diambil }\end{array}$ \\
\hline & b. Subjek tidak teliti dalam operasi hitung \\
\hline & $\begin{array}{l}\text { c. Subjek menggunakan prosedur yang benar tetapi tidak } \\
\text { menyelesaikannya }\end{array}$ \\
\hline $\begin{array}{l}\text { Encoding } \\
\text { (hasil akhir) }\end{array}$ & $\begin{array}{l}\text { a. Subjek tidak mampu menemukan dan menuliskan hasil } \\
\text { akhir dari soal dengan benar }\end{array}$ \\
\hline (Jenis E) & $\begin{array}{l}\text { b. Subjek tidak mampu menginterpretasikan jawaban dengan } \\
\text { benar sesuai dengan kesimpulan }\end{array}$ \\
\hline
\end{tabular}

Instrumen yang digunakan antara lain lembar soal dan pedoman wawancara. Lembar soal terdiri dari tiga soal uraian dengan konteks scientific (ilmiah). Karakteristik soal nomor 1 adalah untuk mengukur kesalahan subjek dalam proses formulate atau merumuskan informasi dan permasalahan secara matematis. Soal nomor 2 untuk mengukur kesalahan subjek dalam proses employ atau menggunakan informasi, fakta, kosep, 
DOI: https://doi.org/10.24127/ajpm.v9i4.2685

dan penalaran dalam matematika. Sedangkan soal nomor 3 untuk mengukur kesalahan subjek dalam proses interpret atau menafsirkan suatu persoalan berdasarkan informasiinformasi yang ada pada soal. Pengambilan subjek menggunakan metode purposive sampling yaitu teknik pengambilan subjek dipilih dengan kriteria tertentu (Sugiyono, 2015). Pertimbangan pemilihan subjek yang digunakan dalam penelitian ini adalah siswa yang berusia 15 tahun. Hasil pekerjaan siswa tersebut kemudian dikelompokkan berdasarkan jenis atau tipe kesalahan yang dilakukan siswa dengan menggunakan teori kesalahan Newman (NEA) dan memilih siswa dalam hal ini siswa yang melakukan kesalahan terbanyak untuk dijadikan subjek pada tahap wawancara.

Analisis data untuk mengetahui jenis kesalahan yang dilakukan subjek menggunakan indikator dan pedoman wawancara berdasarkan metode NEA (Newman's Error Analysis). Indikator yang digunakan untuk mengetahui jenis kesalahan yang dilakukan subjek dalam menyelesaikan soal diuraikan dalam Tabel 1.

\section{HASIL DAN PEMBAHASAN}

Penelitian ini mengguanak 3 siswa kelas X MIPA 3 SMA Negeri 1 Tuntang yang berusia 15 tahun untuk dijadikan sebagai subjek penelitian yaitu Ainindia Latifa Zahra (ALZ), Vina Khusni Khabibah (VKK), dan Astika Ayu W (AAW), dimana ketiga subjek tersebut sesuai dengan kriteria subjek peneliti yaitu subjek yang melakukan kesalahan terbanyak dari ketiga soal, mampu bekerja sama dengan peneliti untuk terlibat dalam penelitian, dan mampu berkomunikasi dengan baik secara lisan. Berikut hasil dan pembahasan data penelitian subjek ALZ, VKK, dan AAW mengenai ketiga soal PISA konten change and relationship.

1. Soal PISA Nomor 1

a) Karakteristik Soal Nomor 1

Soal nomor 1 digunakan untuk melihat kemampuan subjek dalam proses formulate atau merumuskan informasi dan permasalahan secara matematis dengan konteks ilmiah atau ilmu pengetahuan. Soal yang digunakan pada nomor 1 ini adalah soal PISA konten change and relationship dengan topik "Kapal Barang" yang dapat dilihat pada Gambar 2.

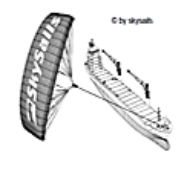

95\% perdagangan didunia dilakukan melalui jalur transportasi laut, kurang lebih $50.000 \mathrm{kapal}$ container (kapal barang). Diman sebagian besar kapal tersebut menggunakan bahan bakar solar. Para insinyur berencana mengembangkan kapal dengan memanfaatkan tenaga angin yaitu menambahkan parasut pada kapal untuk membantu mengurangi konsumsi solar dan dampak bahan bakar terhadap lingkungan.

Kapal ini bernama NewWave yang merupakan kapal barang. Namun, karena biaya bahan bakar solar tinggi yaitu sebesar 0.42 dolar per liter, pemilik kapal NewWave sedang berpikir untuk melengkapi kapal mereka dengan parasut. Diperkirakan parasut seperti itu berpotensi mengurangi konsumsi solar sekitar $20 \%$ secara keseluruhan.

Nama :NewWave $\begin{array}{ll}\text { Nama } & \text { :NewWave } \\ \text { Tipe } & \text { : Kapal barang }\end{array}$

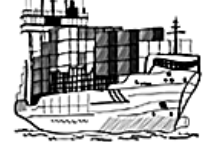

Panjang : $117 \mathrm{~m}$

Luas : $18 \mathrm{~m}^{2}$

Kapasitas kapal : 12000 ton

Kecepatan maksimum : 19 knots (mil laut per jam)

Penggunaan solar setiap tahunnya apabila tanpa parasut adalah sekitar 3.500.000 liter.

Untuk biaya melengkapi kapal dengan parasut sebesar 2.500 .000 dolar.

knots : satuan kecepatan (mil laut per jam)

Setelah sekitar berapa tahun penghematan bahan bakar solar akan menutupi biaya parasut? Berikan perhitungan untuk mendukung jawabanmu! Ditejemahkan dari soal PISA tahun 2012
(http $/ /$ www.oecd.org/pisaitestPISA\%202012\%items\%20for\%20release_ENGLISH.pdf)

Gambar 2. Soal PISA Nomor 1. 
b) Analisis Kesalahan Subjek Pada Soal Nomor 1

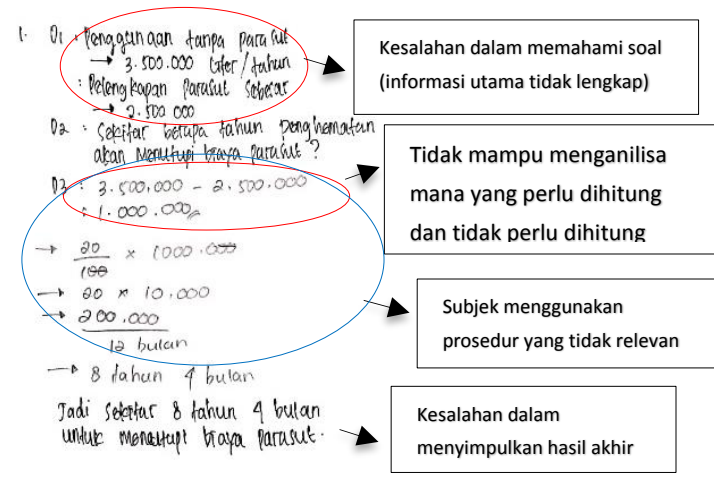

Gambar 3. Hasil pekerjaan subjek ALZ nomor 1.

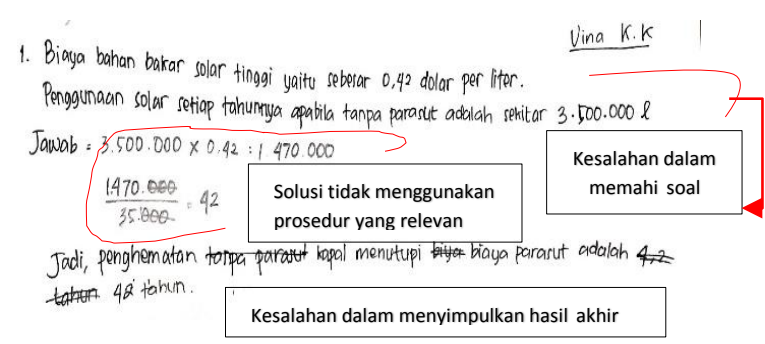

Gambar 4. Hasil pekerjaan subjek VKK nomor 1.

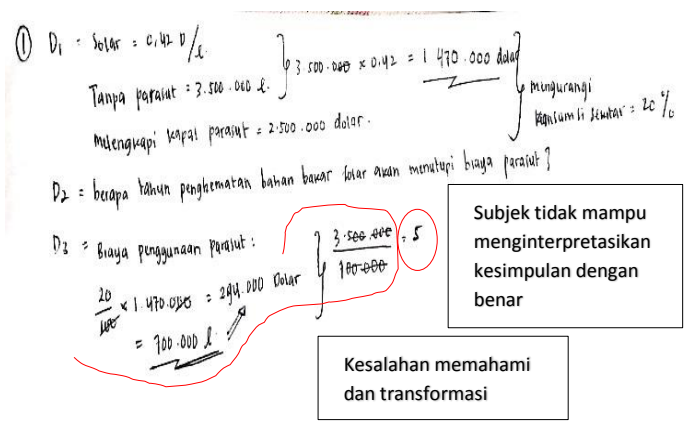

Gambar 5. Hasil pekerjaan subjek AAW nomor 1

Berdasarkan hasil pekerjaan subjek pada soal nomor 1 (Gambar 3-5), subjek ALZ dan VKK melakukan kesalahan dalam memahami soal (comprehension), yaitu tidak mampu menyatakan informasi penting yang diketahui yang memuat informasi utama dalam soal secara lengkap. Hal tersebut didapatkan saat melakukan wawancara dengan subjek, dimana subjek ALZ menyadari informasi yang diketahui tersebut belum lengkap karena yang ditulis oleh subjek merupakan informasi penting yang subjek pahami. Sedangkan subjek VKK mengetahui informasi yang diketahui dalam soal namun hanya mampu menyebutkan informasi berdasarkan jawaban yang subjek tulis. Subjek menyadari bahwa informasi tersebut belum cukup untuk menjawab pertanyaan pada soal. Berbeda dengan subjek AAW, subjek AAW mampu memahami dan menyatakan informasi penting yang diketahui pada soal serta memahami apa yang ditanyakan pada soal.

Selain itu, ketiga subjek juga melakukan kesalahan transformasi, yaitu subjek ALZ dan VKK tidak mampu mengubah informasi maupun permasalahan yang terdapat pada soal ke dalam bentuk matematika, dan tidak mampu merencanakan solusi dengan menggunakan prosedur matematika yang relevan. Subjek VKK mampu merencanakan solusi awal dengan benar tetapi tidak menuliskan keterangan proses tersebut untuk mencari nilai apa. Subjek VKK juga tidak mampu menganalisa mana yang diperlukan dan yang tidak diperlukan untuk dihitung. Hal tersebut didapatkan oleh peneliti saat melakukan wawancara dengan subjek, dimana langkah penyelesaian yang subjek ALZ lakukan adalah dengan berpedoman pada informasi yang subjek ketahui kemudian subjek merencanakan solusi yang subjek pahami tanpa mempertimbangkan apakah hal itu benar dan diperlukan atau tidak. Sedangkan subjek VKK merasa terkecoh dengan menghitung hal-hal yang sebenarnya tidak diperlukan untuk dihitung sehingga subjek tidak mampu menggunakan solusi secara matematis dalam hal ini solusi yang digunakan tidak relevan. 
DOI: https://doi.org/10.24127/ajpm.v9i4.2685

Sedangkan subjek AAW mampu merencanakan solusi tetapi tidak menggunakan prosedur matematika yang relevan. Hal tersebut didapatkan oleh peneliti saat melakukan wawancara, dimana subjek AAW kurang memahami makna dari pertanyaan sehingga langkah terakhir yang dilakukan subjek tidak tepat.

Berdasarkan hasil pekerjaan dan wawancara, ketiga subjek juga melakukan kesalahan encoding, yaitu kesalahan dalam menuliskan, menyimpulkan, atau menginterpretasikan hasil akhir, dimana subjek ALZ dan VKK mampu menginterpretasikan kesimpulannya namun hasil akhirnya tidak tepat. Sedangkan subjek AAW tidak mampu menyimpulkan, menuliskan, atau menginterpretasikan hasil akhir yang diperoleh dengan benar dikarenakan subjek kurang yakin dengan jawaban akhir yang diperoleh.

2. Soal PISA Nomor 2

a) Karakteristik Soal Nomor 2

Soal nomor 2 digunakan untuk melihat kemampuan subjek dalam proses employ atau menggunakan informasi, fakta, kosep, dan penalaran dalam matematika dengan konteks ilmiah atau ilmu pengetahuan. Soal yang digunakan pada nomor 2 ini adalah soal PISA konten change and relationship dengan topik "PLTA" yang dapat dilihat pada Gambar 6.

Zedtown ingin memperkirakan biaya dan keuntungan yang akan dihasilkan dengan membangun pembangkit listrik tenaga angin. Walikota Zedtown mengusulkan rumus berikut untuk memperkirakan keuntungan finansial $\rightarrow F$ dolar, selama beberapa tahun $\rightarrow y$, jika mereka membangun model E-82 (keterangan model E-82 tertera di nomor 3 )

Zedtown : nama kota

$$
F=400000 y-3200000
$$

Berdasarkan rumusnya, berapa minimum tahun pembangkit E-82 beroperasi yang diperlukan untuk menutupi biaya pembangunan pembangkit listrik tenaga angin?

Diterjemahkan dari soal PISA tahun 2012 (http://www.oecd.org/pisa/test/PISA\%202012\%items\%20for\%20release_ENGLISH.pdf)

Gambar 6. Soal PISA nomor 2.

b) Analisis Kesalahan Subjek Pada Soal Nomor 2

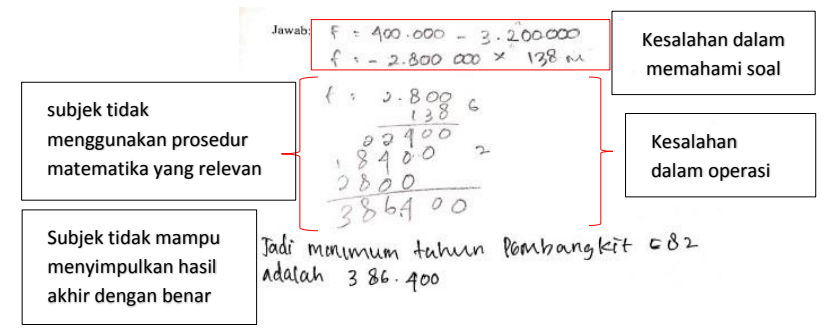

Gambar 7. Hasil pekerjaan subjek ALZ nomor 2.

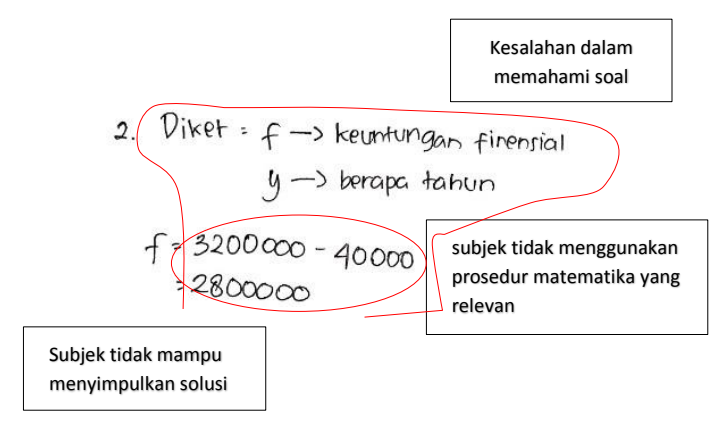

Gambar 8. Hasil pekerjaan subjek VKK nomor 2 . 
DOI: https://doi.org/10.24127/ajpm.v9i4.2685

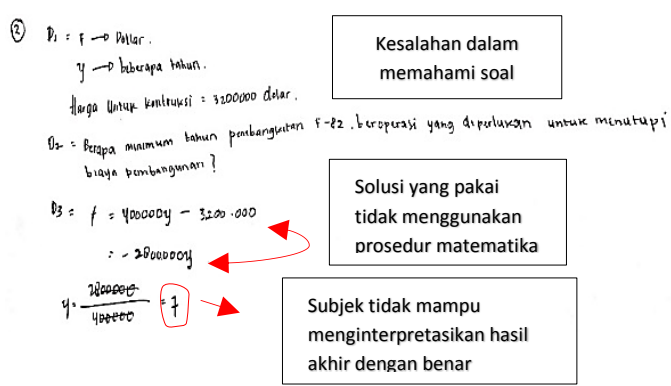

Gambar 9. Hasil pekerjaan subjek AAW nomor 2 .

Berdasarkan hasil pekerjaan subjek pada soal nomor 2 (Gambar 7-9), ketiga subjek melakukan kesalahan dalam memahami soal (comprehension) yaitu subjek ALZ tidak mampu menyatakan informasi penting yang diketahui yang memuat informasi utama dalam soal. Kesalahan tersebut tampak dari hasil pekerjaan subjek, dimana subjek ALZ tidak menuliskan apa yang diketahui dan apa yang ditanyakan pada soal, namun langsung menuliskan rumus yang terdapat pada soal. Subjek VKK mampu menyatakan informasi yang diketahui pada soal, namun tidak dapat memahami soal maupun apa yang ditanyakan pada soal. Kesalahan tersebut tampak dari hasil pekerjaan dimana subjek VKK menuliskan apa yang diketahui namun menuliskan rumus yang berbeda dari rumus yang diketahui pada soal. Subjek AAW tidak mampu memahami maupun memaknai beberapa informasi yang diketahui pada soal dan tidak mampu memahami maksud pertanyaan pada soal. Kesalahan tersebut tampak dari hasil pekerjaan dan wawancara, dimana subjek AAW tidak mampu memahami makna dari pertanyaan yang diajukan pada soal maupun rumus yang diberikan.

Ketiga subjek juga melakukan kesalahan transformasi (transformation) berdasarkan hasil pekerjaan dan wawancara, yaitu subjek ALZ, VKK, dan AAW tidak mampu mengubah informasi yang terdapat pada soal ke dalam bentuk matematika, subjek tidak menggunakan prosedur matematika yang relevan. Kesalahan tersebut tampak saat subjek ALZ mampu merencanakan solusi, yaitu menggunakan rumus namun tidak mampu menggunakan prosedur matematika yang relevan. Sedangkan kesalahan subjek VKK tampak saat subjek mengubah rumus yang terdapat pada soal dimana hal tersebut merupakan prosedur matematika yang tidak relevan. Selain itu, subjek ALZ melakukan kesalahan dalam proses penyelesaian (process skill), yaitu subjek melakukan kesalahan dalam operasi hitung perkalian bilangan bulat. Hal tersebut didapatkan saat melakukan wawancara dengan subjek, dimana subjek ALZ menyadari bahwa operasi hitungnya salah yang mengakibatkan jawaban menjadi tidak realistis.

Selain itu, ketiga subjek juga melakukan kesalahan encoding, kesalahan dalam menuliskan, menyimpulkan, atau menginter-pretasikan hasil akhir. Hal tersebut didapatkan oleh peneliti dari hasil pekerjaan subjek dan saat melakukan wawancara dengan subjek, dimana subjek ALZ tidak mampu menyimpulkan solusi yang sesuai dengan apa yang ditanyakan pada soal, dalam hal ini satuan dari nilai 386.400 adalah Rupiah. Selain itu, subjek ALZ juga tidak mampu menemukan hasil akhir dengan benar. Begitu pula dengan Subjek VKK, subjek tidak mampu menemukan hasil akhir dengan benar, subjek juga tidak mampu menuliskan kesimpulan dari hasil yang diperoleh. Subjek merasa ragu dengan hasil akhir yang diperoleh. Kesalahan subjek dalam menyimpulkan solusi tampak dari jawaban subjek yang tidak realistis dalam wawancara yang menyatakan bahwa satuan dari hasil akhir adalah "dolar". Hal itu 
DOI: https://doi.org/10.24127/ajpm.v9i4.2685

membuktikan bahwa subjek tidak mampu menyimpulkan solusi sesuai dengan apa yang ditanyakan pada soal. Subjek AAW tidak mampu menyimpulkan, menuliskan, atau menginterpretasikan hasil akhir yang diperoleh dengan benar, Kesalahan ini tampak saat subjek menuliskan "7" diakhir langkah penyelesaian tanpa memberikan keterangan berupa satuan.

\section{Soal PISA Nomor 3}

a) Karakteristik Soal Nomor 3

Soal nomor 3 digunakan untuk melihat kemampuan subjek dalam proses interpret atau menafsirkan suatu persoalan berdasarkan informasi-informasi yang ada pada soal dengan konteks ilmiah atau ilmu pengetahuan. Soal yang digunakan pada nomor 3 ini adalah soal PISA konten change and relationship dengan topik "PLTA" yang dapat dilihat pada Gambar 10.

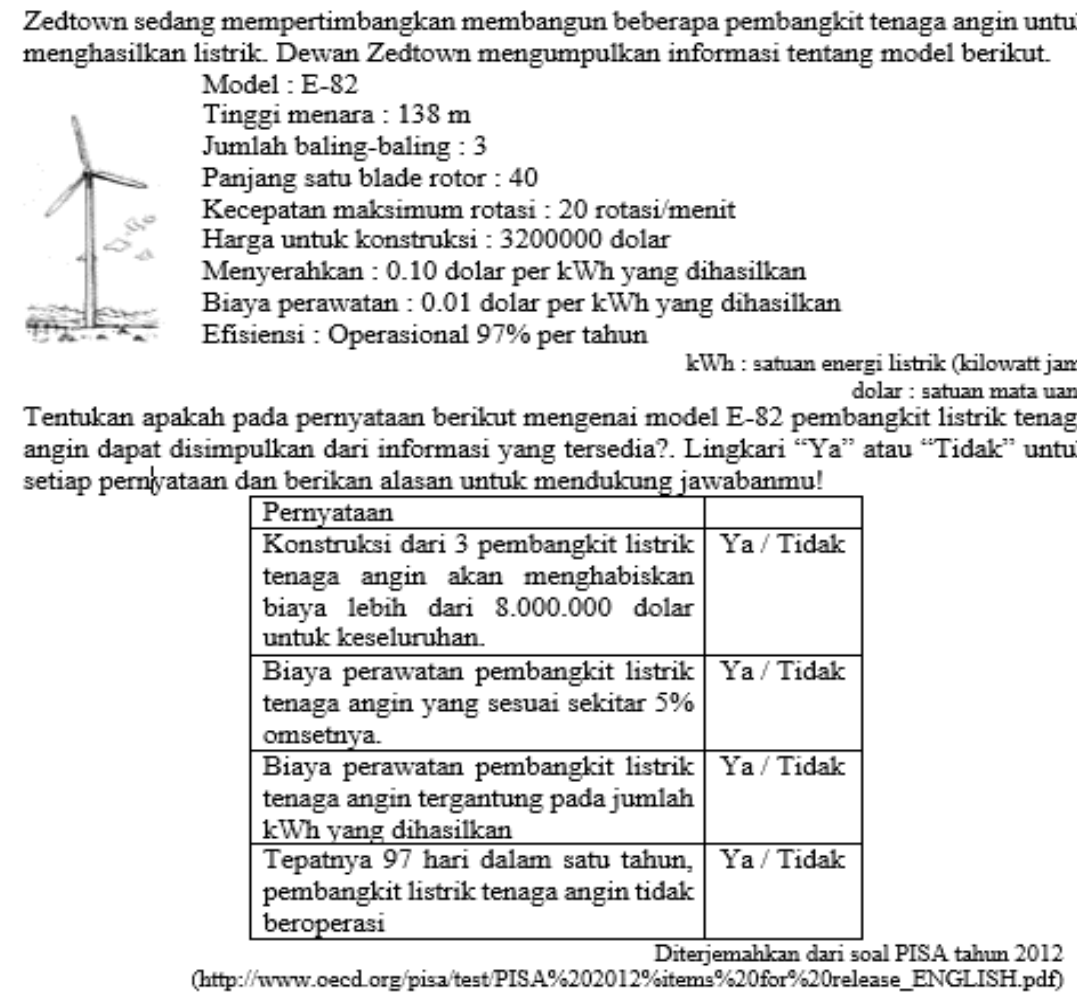

\section{Gambar 10. Soal PISA Nomor 3}

\section{b) Analisis Kesalahan Subjek Pada \\ Soal Nomor 3}

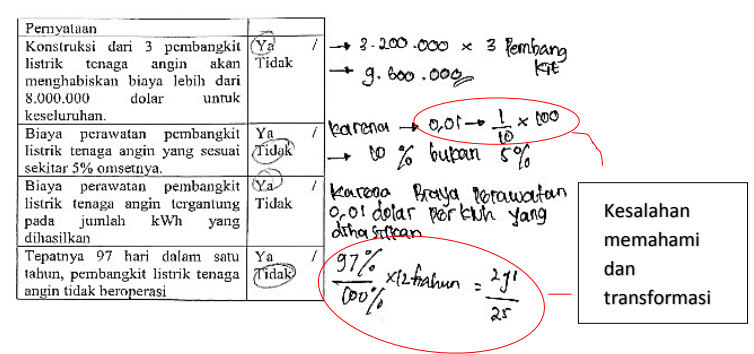

Gambar 11. Hasil pekerjaan subjek ALZ nomor 3.

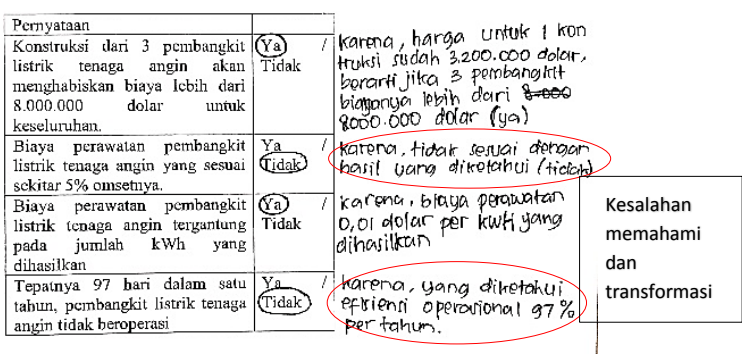

Gambar 12. Hasil pekerjaan subjek VKK nomor 3. 


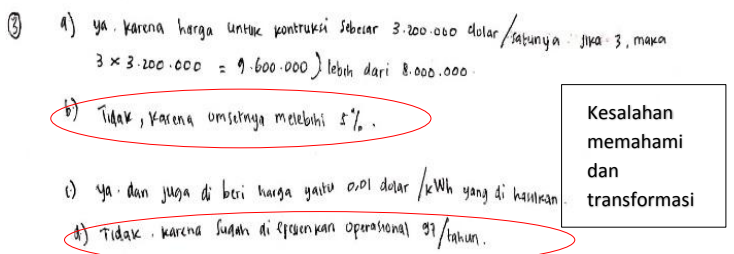

Gambar 13. Hasil pekerjaan subjek AAW nomor 3.

Berdasarkan hasil pekerjaan subjek pada soal nomor 3 (Gambar 1113), ketiga subjek melakukan kesalahan pada pernyataan kedua dan keempat, yaitu subjek tidak mampu memberikan alasan dengan tepat. Pada pernyataan kedua, ketiga subjek melakukan kesalahan yang sama yaitu kesalahan memahami (comprehension) dan transformasi (transformasion). Hal tersebut didapatkan oleh peneliti dari hasil pekerjaan subjek dan saat melakukan wawancara dengan ketiga subjek. Subjek ALZ mampu menyatakan informasi yang diketahui atau yang berkaitan dengan pernyataan, namun subjek tidak mampu memahami beberapa informasi penting dari pernyataan tersebut, yaitu tidak memahami arti "5\% omset". Selain itu subjek ALZ mampu merencanakan solusi dengan benar namun tidak mampu mengubah informasi yang terdapat pada soal ke dalam bentuk matematika, yaitu subjek tidak mampu mengubah nilai dari 0,01 ke dalam bentuk pecahan persen dengan benar yaitu 0,01 sama dengan $\frac{1}{10} \times 100=10 \%$. Hal ini mengakibatkan alasan yang diperoleh atau kesimpulan yang diperoleh subjek tidak tepat walaupun hasil akhirnya benar (Tidak). Subjek VKK juga mampu menyatakan informasi yang diketahui atau yang berkaitan dengan pernyataan, namun subjek tidak mampu memahami makna informasi penting dari pernyataan kedua yaitu subjek menganggap informasi yang ada di pernyataan tidak tertera di keterangan yang terdapat pada soal. Selain itu subjek VKK tidak mampu memberikan alasan yang tepat dengan perspektif ilmu matematika walaupun hasil akhirnya benar (Tidak). Sedangkan kesalahan yang dilakukan subjek AAW pada pernyataan kedua yaitu subjek tidak mampu memahami informasi pada pernyataan dan soal. Subjek AAW juga tidak mampu menggunakan solusi dengan prosedur matematika yang relevan. Kesalahan tersebut tampak saat subjek menuliskan "karena omsetnya melebihi 5\%" tanpa memberikan keterangan "melebihi" itu diperoleh darimana. Subjek mampu merencanakan solusi namun solusi yang digunakan tidak relevan dan subjek tidak mampu memberikan alasan dengan perspektif matematika walaupun subjek menjawab dengan benar yaitu (Tidak).

Pada pernyataan keempat, ketiga subjek juga melakukan kesalahan yang sama yaitu kesalahan dalam memahami (comprehension) dan transformasi (transformasion). Hal tersebut didapatkan dari hasil pekerjaan subjek dan saat melakukan wawancara dengan ketiga subjek. Subjek ALZ tidak mampu memahami makna informasi yang terdapat pada pernyataan maupun informasi yang diketahui pada soal, dan tidak mampu menggunakan langkah atau prosedur matematika yang relevan. Sedangkan subjek VKK tidak mampu memahami informasi yang terdapat pada pernyataan, yaitu subjek meyakini bahwa informasi pada pernyataan sama dengan informasi yang diketahui pada soal. Selain itu subjek VKK tidak mampu menjawab atau memberikan alasan dengan perspektif ilmu matematika. Kesalahan yang dilakukan subjek AAW pada pernyataan keempat adalah subjek tidak mampu memahami infromasi yang terdapat pada pernyataan, yaitu subjek meyakini 
bahwa informasi pada pernyataan sama dengan informasi yang diketahui pada soal. Selain itu subjek tidak mampu menjawab atau memberikan alasan dengan perspektif ilmu matematika.
Terkait hasil dan pembahasan di atas, peneliti menyimpulkan analisis hasil tes dan wawancara pada Tabel 2.

Tabel 2. Daftar kesalahan yang dilakukan subjek penelitian.

\begin{tabular}{cccc}
\hline \multirow{2}{*}{ Subjek Penelitian } & \multicolumn{2}{c}{ Tes Tertulis dan Wawancara (Jenis Kesalahan) } \\
\cline { 2 - 4 } & Soal Nomor 1 & Soal Nomor 2 & $\begin{array}{c}\text { Soal Nomor 3 } \\
\text { (Pernyataan 2 dan 4) }\end{array}$ \\
\hline Subjek ALZ & B, C, E & B, C, D, E & B, C \\
Subjek VKK & B, C, E & B, C, E & B, C \\
Subjek AAW & B, C, E & B, C, E & B, C \\
\hline
\end{tabular}

\begin{abstract}
Berdasarkan Tabel 2, jenis kesalahan terbesar terjadi dalam memahami soal (B), transformasi (C), dan encoding (E). Kesalahan dalam memahami soal menyebabkan siswa tidak mampu memahami informasi yang diketahui dan ditanyakan pada soal. Hasil ini sejalan dengan penelitian Wati, \& Murtiyasa (2016) yang mengatakan bahwa siswa yang tidak mampu memahami soal tidak dapat memaknai apa yang diketahui dan ditanyakan pada soal. Begitu pula dengan hasil penelitian Oktaviana (2018) dimana siswa yang tidak mampu memahami maksud dari soal merupakan penyebab kesalahan memahami siswa. Kristianto, dkk. (2019) menambahkan bahwa siswa dapat membaca dengan benar tetapi tidak dapat memahami istilah yang terdapat pada soal secara keseluruhan.
\end{abstract}

Kesalahan transformasi juga menyebabkan siswa tidak mampu menjabarkan dan mengubah informasi pada soal ke dalam bentuk matematika, siswa juga tidak mampu merencanakan solusi dengan benar, dan tidak mampu menggunakan prosedur matematika yang relevan. Hasil ini sejalan juga dengan penelitian (Wati \& Murtiyasa, 2016) yang mengatakan bahwa kemampuan penalaran dan kreativitas siswa masih kurang dan rendah dalam memecahkan masalah konteks nyata dan memanipulasi ke dalam bentuk aljabar. Begitu pula dengan penilitian Cahyanto (Cahyanto, 2017) yang mengatakan bahwa siswa kurang terampil dalam menerapkan perhitungan ke dalam bentuk rumus, kurang melatih diri menyelesaikan soal yang berbasis konteks nyata. Siswa yang tidak teliti dalam proses pengerjaan maupun mengaplikasikan informasi ke dalam rumus menjadi penyebab kesalahan transformasi (Rohmah \& Sutiarso, 2018). Berbeda dengan penelitian sebelumnya yang berkaitan dengan soal PISA, pada penelitian ini siswa mengalami kesalahan encoding yang menyebabkan siswa tidak mampu menginterpretasikan jawaban dengan benar sesuai dengan kesimpulan. Penyebab lain siswa tidak menuliskan hasil akhir adalah siswa tidak terbiasa dan menganggap itu tidak perlu. Sejalan dengan hasil penelitian yang dilakukan oleh Farida (2015) yang menyatakan bahwa siswa tidak terbiasa menuliskan kesimpulan dari suatu pertanyaan.

Berdasarkan hasil wawancara yang menjadi penyebab siswa melakukan kesalahan adalah siswa kurang berminat untuk mengerjakan soal karena terlalu sulit, malas membaca soal dengan teliti, dan siswa kurang 
memahami konsep aljabar. Hal ini sejalan dengan penelitian Ambarwati, dkk. (2018) yang mengatakan bahwa faktor penyebab kesalahan yaitu lemahnya minat dan kurangnya motivasi siswa dalam menghadapi soal, serta lemahnya kemampuan siswa dalam menggunakan konsep aljabar. Oleh karena itu meningkatkan prestasi matematika siswa SMA dalam program PISA dengan memperhatikan kesalahan yang sering terjadi sesuai dengan tahapan teori kesalahan Newman dalam menyelesaikan soal adalah hal penting dilakukan.

\section{KESIMPULAN DAN SARAN}

Kesalahan yang paling banyak dilakukan oleh subjek dalam menyelesaikan soal matematika PISA pada konten change and relationship berdasarkan NEA (Newman's Error Analysis) dengan menggunakan konteks ilmiah atau ilmu pengetahuan dan komponen proses yang berbeda-beda antara lain tidak mampu memahami soal dengan baik (comprehension). Selain itu, subjek tidak mampu mengubah permasalahan yang terdapat pada soal kedalam bentuk matematika (transformation), hal ini disebabkan subjek tidak dapat memahami informasi yang terdapat pada soal. Kemudian subjek juga tidak mampu menuliskan atau menyimpulkan hasil akhir (encoding). Berdasarkan hasil wawancara menunjukkan bahwa faktor penyebab subjek melakukan kesalahan adalah subjek menganggap soal sulit karena membutuhkan penalaran yang tinggi. Subjek tidak dapat membayangkan solusi yang tepat dan mengalami kebingungan dalam menyaring informasi yang diperlukan untuk menyelesaikan soal sesuai dengan prosedur matematika yang relevan. Kemudian kurangnya minat dan motivasi siswa dalam menyelesaikan soal juga menjadi penyebab siswa melakukan kesalahan.

Diharapkan penelitian ini dapat dijadikan sebagai sarana refleksi bagi siswa dan guru untuk melakukan perbaikan terhadap kesalahan-kesalahan yang dilakukan siswa dalam mengerjakan soal matemaatika PISA konten change and relationship. Bagi peneliti lain, diharapkan penelitian ini dapat dijadikan sebagai acuan bagi peneliti-peneliti selanjutnya yang mempunyai relevansi dalam variabelvariabelnya. Keterbatasan dan kekurangan dalam penelitian ini hendaknya dapat dijadikan pembelajaran untuk penelitian yang lebih baik.

\section{DAFTAR PUSTAKA}

Ambarwati, B., Hoerniasih, N., \& Abadi, A. P. (2018). Analisis Kesalahan Siswa dalam Menyelesaikan Masalah Aljabar (Change And Relationship) PISA. Prosiding Seminar Nasional Matematika Dan Pendidikan Matematika (Sesiomadika) 2018, 1(1), 563-571. http://journal.unsika.ac.id/index.ph $\mathrm{p} / \mathrm{sesiomadika}$

Cahyanto, M. N. (2017). Kesalahan Siswa Kelas Viii Dalam Memecahkan Soal Matematika Model Pisa Konten Space and Shape. Univesitas Muhammadiyah Surakarta, http://eprints.ums.ac.id/53280/11/ Naskah Publikasi.pdf

Djadir, Awi, \& Sulhijrah. (2018). Deskripsi Kesalahan Siswa dalam Menyelesaikan Soal Matematika Berbasis PISA pada Konten Change and Relationship. Issues in Mathematics Education, 2(2), 112118. 
DOI: https://doi.org/10.24127/ajpm.v9i4.2685

Elsa, S., \& Syam, S. S. (2017). Peran Guru dalam Meningkatkan Kemampuan Literasi Matematika Siswa Indonesia. Seminar Matematika Dan Pendidikan Matematika Uny, November 2017, 30-35.

Farida, N. (2015). Analisis Kesalahan Siswa SMP Kelas VIII Dalam Menyelesaikan Masalah Soal Cerita Matematika. AKSIOMA: Jurnal Program Studi Pendidikan Matematika, 4(2), 42-52.

Fitrah, M. (2017). Pembelajaran Berbasis Masalah Untuk Meningkatkan Pemahaman Konsep Matematika Pada Materi Segiempat Siswa Smp. KALAMATIKA Jurnal Pendidikan Matematika, 2(1), 51. https://doi.org/10.22236/kalamatik a.vol2no1.2017pp51-70

Kristianto, E., Mardiyana, \& Saputro, D. R. S. (2019). Analysis of Students' Error in Proving Convergent Sequence using Newman Error Analysis Procedure. Journal of Physics: Conference Series, 1180(1). https://doi.org/10.1088/ 1742-6596/1180/1/012001

Mursalin, Fauzi, \& Israwati. (2013). Kemampuan Siswa dalam Menyelesaikan Soal Matematika dalam Bentuk Pemecahan Masalah Bagi Siswa Kelas V SD Negeri 1 Pagar Air Aceh Besar. Journal Ilmiah Pendidikan Guru Sekolah Dasar, 2(2), 38-44.

Murtiyasa, B., \& Perwita, W. R. G. (2020). Analysis of mathematics literation ability of students in completing PISA-oriented mathematics problems with changes and relationships content. Universal Journal of Educational Research, 8(7), 3160-3172. https://doi.org/10.13189/ujer.2020. 080745
Murtiyasa, B., Rejeki, S., \& Ishartono, N. (2020). Profile of Students' Error in Solving Mathematics Word Problems Based on PISA Frameworks. Advances in Social Science, Education and Humanities Research, Volume 467 Proceedings of the SEMANTIK Conference of Mathematics Education (SEMANTIK 2019), 467(Semantik 2019), 135-137. https://doi.org/10.2991/assehr.k.20 0827.131

Novferma, N. (2016). Analisis Kesulitan Dan Self-Efficacy Siswa Smp Dalam Pemecahan Masalah Matematika Berbentuk Soal Cerita. Jurnal Riset Pendidikan Matematika, 3(1), 76. https://doi.org/10.21831/jrpm.v3i1. 10403

OECD. (2012). Program for International Student Assessment (PISA).

OECD. (2019). PISA 2018 Results. Combined Executive Summaries. Journal of Chemical Information and Modeling, 53(9), 1689-1699. https://doi.org/10.1017/CBO97811 107415324.004

Oktaviana, D. (2018). Analisis Tipe Kesalahan Berdasarkan Teori Newman Dalam Menyelesaikan Soal Cerita Pada Mata Kuliah Matematika Diskrit. Edu Sains: Jurnal Pendidikan Sains \& Matematika, 5(2), 22. https://doi.org/10.23971/eds.v5i2.7 19

Rohmah, M., \& Sutiarso, S. (2018). Analysis problem solving in mathematical using theory Newman. Eurasia Journal of Mathematics, Science and Technology Education, 14(2), 671681. https://doi.org/10.12973/ ejmste/80630 
DOI: https://doi.org/10.24127/ajpm.v9i4.2685

Sholihah, D., Purnomo, E. A., Aziz, A., \& Ampuni, D. (2019). Analisis Kesalahan Soal Pisa Konten Ruang Dan Bentuk. Seminar Nasional Edusainstek FMIPA UNIMUS, 221-230.

Stacey, K. (2011). The PISA view of mathematical literacy in Indonesia. Journal on Mathematics Education, 2(2), 95-126. https://doi.org/10.22342/jme.2.2.74 6.95-126

Sugiyono. (2015). Metode Penelitian Kuantitatif, Kualitatif, dan $R \& D$. Alfabeta. Bandung.

Trapsilo, T. E. B. (2016). Analisis Kesalahan Menurut Teori Newman dalam Menyelesaikan Soal Cerita Materi Persamaan Linier Dua Variabel Pada Siswa Kelas IX SMP N 1 Banyubiru. Universitas Kristen Satya Wacana. Diakses Tanggal 19 Maret $2019 \quad$ Dari http://repository.uksw.edu/handle/1 23456789/9775.
Wati, E. H., \& Murtiyasa, B. (2016). Kesalahan Siswa Smp Dalam Menyelesaikan Soal Matematika Berbasis Pisa Pada Konten Change and Relationship. Prosiding, Knpmp I, 199-209. https://publikasiilmiah.ums.ac.id/bi tstream/handle/11617/6959/21_77_ Makalah Rev Erna Hartika Wati.pdf;sequence $=1$

White, A. L. (2010). Numeracy, Literacy and Newman's Error Analysis. Allan Leslie White Journal of Science and Mathematics Education in Southeast Asia, 33(2), 129-148.

Wilkens, H. J. (2011). Textbook approval systems and the Program for International Assessment (PISA) results: A preliminary analysis. Journal Hendrianne J.Journal Hendrianne J. Wilkens, 474(2), 63-74. 